\title{
CRIMINALITY AND MENTAL ILLNESS-TWO FACES OF THE SAME COIN
}

\author{
PHIITP Q. Roche, M.D.†
}

$\mathrm{P}$ SYCHIATRISTS WILI WELCOME the Durham opinion that, "existing tests of criminal responsibility are obsolete and should be superseded." In 1951 the right-and-wrong test first met with realistic scrutiny in the Smith case. ${ }^{2}$ Chief Judge Biggs in dissent said:

The Court in compelling the answer to this question [M'Naghten Rule] was adhering to the law of Pennsylvania of over a hundred years standing. It need not be always so. Changes can be effected and reason can be brought to the law of criminal insanity. The rule of M'Naghten's Case was created by decision. Perhaps it is not too much to think that it may be altered by the same means. ${ }^{3}$

The Durham opinion abandons the right-and-wrong rule and likewise rejects the "irresistible impulse" test. In place of these the opinion adopts the essentials of the $1870 \mathrm{New}$ Hampshire rule which states simply that the accused is not criminally responsible if his unlawful act was the product of mental disease or mental defect. This breaks the spell which compelled us to think of new things in old ways and should clear the way for a re-examination of our notions and procedures for determining responsibility of wrongdoers.

The evolution of criminal law has been a chronicle of how conflicts of motivation of both the wrongdoer and the triers have been rationalized in the guilt-fastening process. Motivation is tied up with the notions of knowledge, intent, willfulness and freedom of choice which have never been nor probably ever will be reduced to rational definitions. The M'Naghten test is a creature of such notions and might be better understood if examined in the light of traditional child-rearing. Misbehavior in a child is regarded as a willful attack. The willful child acts contrary to what he is assumed to "know" of our two-value, either-or system of right and wrong. If he "knows" better he is responsible in the sense that he is punishable; the parental

+ Assistant Professor of Psychiatry, University of Pennsylvania; Member, Past Chairman, Committee on Psychiatry and Law, Group for the Advancement of Psychiatry.

${ }^{2}$ P. 864.

${ }^{2}$ United States ex rel. Smith v. Baldi, 192 F. 2d 540 (C.A. 3d, 1951).

${ }^{3}$ Ibid., at 568 . 
counterattack is aimed at the vicious will. If the child does not "know" better, he is not responsible and there is no parental counterattack. In this reflection it would appear that traditional child-rearing is a continuous informal application of the M'Naghten rule. It is clear that this is a process of abstraction going on exclusively inside the parent, and it is the operational prototype of Anglo-American legal procedures for determining responsibility, i.e., punishability, the parental authority and power having been extended to the court.

Our jurisprudence rests too much upon this basis for guilt-fastening and for the inflicting of punishment upon wrongdoers who "know" better. It is a continuation of our child-rearing system into adult life on a community scale of social interaction. The essential question here is whether it works well enough to meet middle twentieth-century social needs. It appears to work well enough as a nominal monitory influence on that part of the community which is already lawabiding; but does it work well enough to deal with certain classes of wrongdoers who are unaffected by punishment or the threat of it, wrongdoers who "know" better, including those with mental illness? Children who do not respond to traditional child-rearing are the neverending supply of the adult maladjusted and antisocial who seldom if ever learn to "know" better.

The test of "irresistible impulse" is a device to lengthen the reach of the M'Naghten rule of "knowledge." It is a reluctant concession, but like the M'Naghten test, the matter which it tests never gets out of the category of the abstract and cannot be reduced to operational definition. The rejection of this test does not imply the rejection of valid observations that certain individuals do struggle with and succumb to unlawful impulses. But to limit the determination of responsibility as with the M'Naghten rule to only a fraction of the morbid process cannot insure full justice to the accused.

For over one hundred years lawyers and medical men have not faced up to Pavlov's assertion that "men are more influenced by words than by the facts of the surrounding reality." The words of the M'Naghten rule relate to no surrounding reality, but do possess the quality of venerable word magic congenial to the ritual and vocabulary of traditional guilt-fastening. Medical men have never found a way to determine "knowledge" of right and wrong in another for no less reason than that the M'Naghten test questions are what Bridgman terms "footless" questions which are unanswerable. 
In the guilt-fastening process too much energy is spent in contests over verbal abstractions which leave little for constructive social actions. An example of this is the Smith case involving a prosecution for murder which came before six courts of record, once before a state board of pardons, once before Oyer Terminer Quarter Sessions Court of Philadelphia, once before Kings County Court of New York, twice before a U.S. district court, twice before a U.S. court of appeals, twice before the Supreme Court of Pennsylvania, three times before the Supreme Court of the United States and once before a lunacy commission. At least thirty-five justices and judges of the federal and state courts and fifteen attorneys never extricated themselves from a "footless" question; the cost to New York, Pennsylvania, and the United States was at least $\$ 250,000$. The whole business was eventually settled when the convicted defendant was examined by competent medical men who were unencumbered by the M'Naghten test questions. They found within an hour that all of the time law enforcement had been dealing with a chronic lunatic.

The Durham opinion will impose on lawyers and physicians alike the pain of facing the facts of surrounding reality. There remains the task of psychiatrists to bring to the law a more articulate and meaningful communication as to the nature of mental illness and its relation to unlawful behavior.

The language of the New Hampshire rule states that the unlawful deed must be a product of mental illness. This invites inspection. The term product denotes separateness and implies causation. Mental illness does not cause one to commit a crime nor does mental illness produce a crime. Behavior and mental illness are inseparable-one and the same thing. A few observations may make this clear. All human beings start out in life as creatures of instincts which are asocial and self-serving. Our child-rearing is intended to modify the instincts for eventual group conformity and mutual security. Childrearing is essentially an imposed conditioning out of which the child is assumed to have acquired a built-in, automatic set of optimal controls of his primary instincts sufficient for the usual stresses of social life. This assumption holds both the dullard and the savant to the same expectations and accountability.

The phenomena of criminality and mental illness are evidence of the insufficiency or breakdown of the built-in controls, relative to en-

4 Ibid., at $\mathbf{5} 40$. 
vironmental stresses. Both are manifest reactive behavior indicative of a losing struggle to maintain a controlled relationship with the social environment. Both can be properly regarded as a product of basically similar conflicts unresolved within the limits set by group norms. This suggests that we cast our focus more on the conflict itself and less on the resultant symptoms. In this light criminality and mental illness cease to be a demoniacal possession which has the selfcontained faculty of turning itself on and off and "causes" one to do wrong; they become more meaningful processes reflecting the breakdown of psychic controls and the release of latent antisocial drives common to all.

This leads to the central question: what are the forces of personality development that determine whether one resolves conflict in acting out in crime or in living out in mental illness? Both are regressively adaptive and are survival gestures in retreat from surrounding reality. In criminality one observes rebellion with destructive action directed outwardly; in mental illness, rebellion with destructive reaction absorbed inwardly. A complementarity is in this picture: it would seem that many criminals are compelled to repeat unlawful acts in order to preserve their sanity, and many law-abiding persons go crazy to avoid crime. From a social standpoint, mental illness has a higher premium in the sense that it spares the group at the expense of the individual. It would appear that the mentally ill person who commits a crime is cursed by a double failure of adaptation. His mental disintegration does not go far enough to nullify the remaining ego which on its own becomes a compliant accessory to his latent unlawful drives. Our hospitals are filled with people whose latent "crimes" are lived out in the disguise of symbols and allegory. In them criminal drives lie behind a bizarre façade of social incapacity. In extreme cases imminent outward attack is often turned on the self in suicide. Such are those who take flight from surrounding reality rather than make outright attack upon it.

The losing struggle for control in social interactions is marked by symptoms which also indicate restitutive efforts to re-establish reality contact once held. Such may be expressed in verbal symbols, body language or motor patterns. The manifest symptoms are not in themselves the conflict, but the outward behavioral aspects of it. Criminality and mental illness bear a kinship in that they demonstrate regressive withdrawal from surrounding reality in some degree and the substitution of fantasy for reality. In both, the break with reality 
is substantial, transcends group norms, is resistive to correction and tends to become a modus vivendi.

When the internalized living-out process is relatively preponderant over the outward acting-out process we are dealing with psychosis. That criminality and mental illness are two faces of the same coin is clearly shown in recent observations of attempts to treat and reform criminals. The acting out of the criminal cannot be touched by insight, but if the acting out can be transformed reciprocally into internalized living out there is some chance of successful outcome. In sum, change the criminal into a neurotic and treat the neurosis.

Manifest psychosis can be relatively short- or long-lived, and the substitution of fantasy may be uncovered in forms running from preverbal body signs and motor behavior to highly intellectualized expressions such as given to posterity by M'Naghten himself:

The Tories in my native city have compelled me to do this. They follow and persecute me wherever I go, and have entirely destroyed my peace of mind. They followed me to France, into Scotland and all over England; in fact, they follow me wherever I go. I can get no rest from them night or day. I cannot sleep at night in consequence of the course they pursue towards me. I believe they have driven me into a consumption. I am sure I shall never be the man I formerly was. I used to have good health and strength, but I have not now. They have accused me of crimes of which I am not guilty; they do everything in their power to harass and persecute me; in fact they wish to murder me. It can be proved by evidence. That's all I have to say. ${ }^{5}$

The Durham opinion will expand the area of inquiry and communication of the medical expert as a witness. Preoccupation with questions of "knowledge" can be relegated to a museum of rituals no longer of service to present social needs. The relationship of criminality to the morbid adaptations of mental illness is a neglected area of observation long in need of scientific study and reorientation to the law. The Durham opinion removes a long-existing barrier to communication between lawyers and physicians.

\footnotetext{
${ }^{5}$ Ellison and Haas, A Recent Judicial Interpretation of the M'Naghten Rule, 4 Brit. Jour. of Delinquency 129 (Oct. 1953).
} 